\title{
WATERS AND SPAS IN THE CLASSICAL WORLD
}

\author{
Ralph Jackson
}

Everywhere in many lands gush forth beneficent waters, here cold, there hot, there both ... in some places tepid and lukewarm, promising relief to the sick ...

So wrote the Elder Pliny in Book XXXI of his Natural History, a section devoted entirely to water, which was the element he considered "lord over all the others". ${ }^{1}$ In Pliny's day the major spas were termed aquae, of which around one hundred are recorded. Many remain unlocated; at some the springs are now dry; at others, due to continued usage, the ancient installations are sealed, or partially or wholly destroyed by subsequent structures. The archaeological investigation of spas is thus a difficult and painstaking process, usually opportunistic as alterations are made to existing buildings. Before turning to the physical remains of the spas themselves, however, I shall briefly survey Greek and Roman medicinal uses of water.

In Homeric times baths were employed primarily to cleanse and refresh, and the provision of washing facilities for a visitor appears to have been a part of aristocratic hospitality. ${ }^{2}$ Already by the time of Hippocrates, however, bathing was regarded as more than a simple hygienic measure. To the cleansing and tonic effect of baths had been added both general and specific healthful and healing properties. Using a combination of hot and cold baths as part of a wider regimen the bodily humours could be adjusted-heating, cooling, moistening, and drying as deemed necessary-to bring them into harmony. Bathing was therefore considered beneficial for most patients. $^{3}$ Like the humoral doctrine itself, this therapeutic use of baths was remarkably long-lived, spanning the entire classical period. Such popularity was no doubt partly due to the fact that baths were both pleasant and, by the Roman imperial period at least, comparatively freely available.

More specifically, warm baths were credited with an indirect nutritive role, whereby a softening of the bather's body prepared it for assimilation of nutriment from food, a Hippocratic notion that was developed by Galen-in the second century AD and Oribasius in the fourth. ${ }^{4}$ Thermal baths were also recommended in the treatment of particular maladies as, for instance, for soothing chest and back pains in pneumonia, promoting good respiration, relieving fatigue, relaxing joints, curing

Ralph Jackson, B.A., FSA, Department of Prehistoric and Romano-British Antiquities, British Museum, London WC1B 3DG.

${ }^{1}$ Pliny, Natural History, XXXI, i-ii.

2 Cf. Homer, Odyssey, XIX, 317.

${ }^{3}$ E.g., Regimen in Acute Diseases, lxv-lxviii.

${ }^{4}$ Hippocrates, Places in Man, xliii. Galen, In Hippocratis de natura hominis, CMG V 9, 1, 106, $15-21$. M.-T. Fontanille, 'Les bains dans la médecine Gréco-romaine' in A. Pelletier (ed.), La médecine en Gaule: villes d'eaux, sanctuaires des eaux, Paris, Picard, 1985. 


\section{Ralph Jackson}

headaches, and promoting the secretion of urine. Cold douches were used to relieve swellings and painful joints, while the addition of herbal oils and extracts extended the powers of warm baths. Aromatic vapour baths were particularly advised for female disorders. ${ }^{5}$

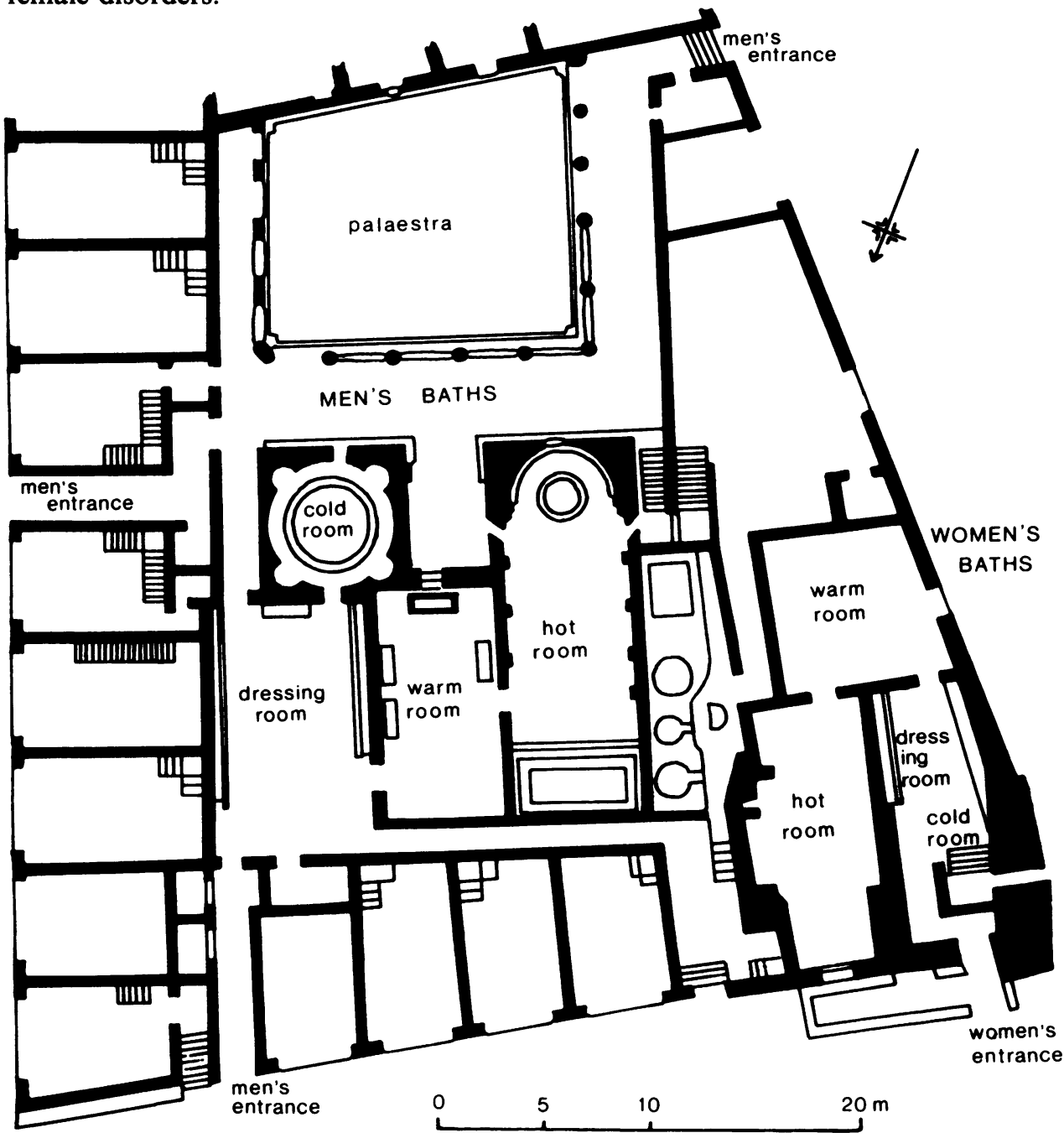

Figure 1. Ground plan of the Forum Baths, Pompeii. Separate facilities were provided for men and women.

The first century BC saw a great upsurge in the use of water treatments, a development inextricably entangled with the general adoption in the Roman world of elaborate suites of baths, increasingly constructed by wealthy individuals or town councils for the benefit of the whole community. The well-preserved baths at

${ }^{5}$ Hippocrates, Regimen in Acute Diseases, lxvi. Aphorisms, V, 25; V, 28. Soranus, Gynaecology, IV, 38. 
Herculaneum and Pompeii serve as examples of the type of facility that became a sine qua non of any self-respecting town (figure 1). After undressing in the changing room the bather progressed through a series of rooms of graded temperature and humidity. Immersion was only a part of the process, and in the heated rooms sweat and grime were scraped from the skin with metal strigils. Basins with hot and cold water were provided for washing and refreshing, and the final stage normally involved the application of oils and unguents. Roman baths were regarded not only as places for cleansing and social intercourse but also as centres of medical treatment, and though some went there to wash, take exercise, socialize, have a massage or a manicure, or have unwanted hair removed, others went for medical treatment or for advice on dietetics from athletics trainers. ${ }^{6}$

Asclepiades, a Greek physician who practised in Rome in the late second century BC, was a forceful advocate of the use of baths in regimens for the sick and for the healthy. He employed cold water extensively as a therapeutic measure both internally and externally administered, in consequence of which Pliny attributed to him the nickname "cold-water giver". 7 Although he had detractors there were many who respected his methods, and hydrotherapy increased in popularity throughout the first century BC. Towards the end of the century one of Asclepiades' followers, Antonius Musa, was responsible for the single most celebrated application of water therapy. In $23 \mathrm{BC}$, according to Suetonius, Augustus "was in such a desperate plight from abscesses of the liver, that he was forced to submit to an unprecedented and hazardous course of treatment. Since hot fomentations gave him no relief, he was led by the advice of his physician Antonius Musa to try cold ones."8 After his unexpected and dramatic cure, Augustus richly rewarded Musa, whose water treatment, despite subsequent less successful applications, was adopted as a fashionable form of therapy. ${ }^{9}$ There seem to have been many imitators keen to cash in on a lucrative practice, like Charmis of Marseilles, who, Pliny recorded, persuaded his wealthy patients to bathe in cold water even during the winter frosts. ${ }^{10}$

Less extreme were the treatments advised by Celsus, who wrote his On medicine several decades after Augustus' cure. He was generally approving of Asclepiades' medicine, not least in the use of baths, which he considered appropriate to many different conditions. As an integral part of a healthy regimen, baths were included in his preventative measures, while as a restorative he recommended them to those who had incurred fatigue or who had become chilled or overheated. Like Hippocrates, he imbued baths with the power to regulate the humoral balance, and he also commended their use in the treatment of many different diseases and disorders, notably skin complaints, "diseases of sinews", gout, wounds, digestive disorders, "wasting diseases", eye diseases and fevers, as well as in convalescence after surgery. Despite Musa's success in treating Augustus, Celsus advised not cold but hot baths

\footnotetext{
${ }^{6}$ Seneca, Epistulae Morales, LVI, 1-2. For archaeological evidence of medical treatment at baths see E. Künzl, 'Operationsräume in römischen Thermen', Bonner Jb., 1986, 186: 491-501.

7 Nat. Hist., XXVI, vii-viii.

${ }^{8}$ Suetonius, Lives of the Caesars, Augustus Ixxxi, 1.

9 Ibid., lix. Dio Cassius, Histories, LIII, 30, 3.

${ }^{10}$ Nat. Hist., XXIX, v, 10.
} 


\section{Ralph Jackson}

for those suffering from liver abscess, warning, indeed, that "all cold things must be especially avoided."11

Baths, then, were considered a vital part of dietetic treatment together with food, drink, rest, exercise, and drugs. From the first century AD onwards they were recommended especially by physicians of the Methodist sect. The Methodists, whose medical doctrines grew from those of Asclepiades and his followers, classed diseases as acute or chronic and saw their causes as due to an excessively constricted or an excessively relaxed state of the body. Their novel two-fold treatment, applied in the remissions of chronic diseases, involved a restorative cycle whereby the patient's strength was built up, followed by a course of treatment aimed at eliminating the disease by altering the bodily condition. Harsh and extreme measures were interspersed with gentler ones, which included the use of baths and of mineral waters both for immersion and for drinking.

Water drinking was one of Asclepiades' "common aids", and Celsus placed water in his "weakest" category of drinks. It was to be substituted for wine and meat if there were signs of impending illness, and copious draughts of cold water were given as a medicine to those with ardent fevers. The "lightest" water, that most suited to the sick and convalescent, was considered to come from springs and rain. ${ }^{12}$ For the poor these had the virtue of being available at little or no expense, unlike the costly concoctions of druggists and physicians.

Soranus, the most famous Methodist physician, saw especial value in baths for relaxation from both physical and mental stress. The softening and loosening effect they had on pregnant women was, he believed, beneficial in the later stages of pregnancy but detrimental in the early stage when the seed or embryo could be shed from an over-relaxed womb. Bathing in natural waters was thought to ease the status strictus in women who suffered from difficult menstruation and to relieve many other disorders of the womb. ${ }^{13}$

Asclepiades, Celsus, and Soranus were interested in water in its various forms inasmuch as it was thought to be of use in healing the sick and preventing disease. Vitruvius and the Elder Pliny, on the other hand, were more concerned to illustrate the marvels of nature, and their lists of sources featured especially those springs reputed to have particular and exceptional properties. Nevertheless, it is interesting to note the broad similarity between the diseases and disorders treated by baths by the medical writers and those which were believed to be cured or relieved by spa therapy. Foremost are "diseases of sinews", gout, skin diseases, stomach disorders, and diseases of the urinary tract. ${ }^{14}$

Vitruvius and Pliny recognized several classes of thermal and medicinal springs, not dissimilar to modern classifications: sulphur springs, whose waters "refresh muscular weakness and sinews" by heating and burning poisonous humours from the body; alum springs, immersion in which was used as a treatment for paralysis, because their

11 Celsus, De Medicina, I, 1-3; 1, 7; II, 17; III, 6; III, 12; III, 20; III, 22; IV, 15; IV, 31; V, 26-28; VI, 6; VII, 26.

12 Ibid., II, 14; II, 18; III, 2; III, 7 .

${ }^{13}$ Soranus, Gynaecology, I, 46; I, 54-56; III, 10-16; III, 28; III, 32; III, 38; III, 44.

${ }^{14} \mathrm{Cf}$. the waters of Bath spa, which are said to benefit those suffering from rheumatism, gout, diseases of the nervous system, skin conditions, dyspepsia, and anaemia. 
warmth opened the pores and restored health; bitumen springs which provided draughts to purge and to heal "interior defects"; alkaline springs, whose waters were taken to purge and to lessen "scrofulous tumours"; and acid springs, draughts of which were drunk to dissolve bladder stone, an effect which Vitruvius explained as happening "by nature, because a sharp and acid juice is present in the soil, and when water currents pass out of it, they are tinctured with acridity". 15

Pliny listed further sources which had powers to heal wounds, dislocations and fractures, and cure gout, foot diseases, sciatica, fever, psoriasis, diseases of the eyes, ears, and head, insanity, and barrenness in women. He also compiled a similarly extensive list of the medicinal uses of sea water, repeating and endorsing the contemporary adage that "for the whole body nothing is more beneficial than salt and sun". Celsus, too, extolled the virtues of warm sea water, notably for those suffering from "relaxing of the sinews" or paralysis. 16

Certain sources were especially renowned for their healing properties and were singled out for mention, as, for example, the intensely cold waters of Aquae Cutiliae, near Rome, which Pliny and Celsus praised for their effectiveness in curing stomach disorders; and the sulphur springs of Aquae Albulae, between Rome and Tivoli, described by Vitruvius, Strabo, and Martial, recommended by Pliny for the healing of wounds, and frequented by Augustus when he was troubled with rheumatism. ${ }^{17}$ As "la Solfatara" the Albula springs are still in use today.

One of the most celebrated spas of antiquity was Baiae, on the north side of the Bay of Naples. It was to his villa nearby that Marius' detractors recommended he retire to see to his failing health after the Social Wars, ${ }^{18}$ and by the later first century BC Baiae had become the most fashionable of Roman spa resorts. Celsus recommended the sulphurous sweat-baths "in the myrtle groves above Baiae"; Strabo characterized the place by its hot springs that were "suited both to the taste of the fastidious and to the cure of disease"; and Pliny believed that "Nowhere ... is water more bountiful than in the Bay of Baiae or with more variety of relief". ${ }^{19}$ The rich, invalids and healthy alike, visited in droves to take the waters and to socialize, and Baiae became as renowned for licentious living as for its thermal facilities. Martial was one of many who wrote of the temptations which snared even the virtuous: ${ }^{20}$

Chaste, and not inferior to the old-world Sabines, straiter-laced, too, than her husband in his sternest mood, Laevina, while she entrusted herself, now to the Lucrine Lake and now to Avernus, and was oft refreshed by the waters of Baiae, fell into flames. She went after a youth, leaving a husband: she arrived a Penelope and departed a Helen!

\footnotetext{
15 Vitruvius, De Architectura, VIII, 4-5; VIII, 17. Pliny, Nat. Hist., XXXI, iii-viii; XXXI, xxxii-xxxiii. ${ }^{16}$ Nat. Hist., XXXI, xlv; XXXI, xxxiii. De Med. III, 27; IV, 2.

${ }^{17}$ Aquae Cutiliae: Celsus, De Med., IV, 12,7. Pliny, Nat. Hist., XXXI, vi. Aquae Albulae: Vitruvius, De Arch., VIII, 3,2. Strabo, Geography, V, iii, 11 (C 238). Martial, Epigrams, I, xii. Suetonius, Lives, Augustus, Ixxxii, 2.

18 Plutarch, Lives, Marius, xxxiv, 2.

${ }_{19}$ Celsus, De Med., II, 17,1. Strabo, Geography, V, iv, 5 (C 244). Pliny, Nat. Hist., XXXI, ii.

${ }^{20}$ Martial, Epigrams, I, lxii.
} 


\section{Ralph Jackson}

The spa facilities at neighbouring Cumae and Puteoli were also popular, and Naples, too, had hot springs and bathing establishments "not inferior to those at Baiae although . . . far short of Baiae in the number of people". 21

With its natural beauty, salubrious climate, and unrivalled spa facilities, the littoral from Naples to Misenum was for long a favourite haunt of emperors and millionaires. At the time of Augustus the luxury maritime villas in the Baiae region were so numerous that it seemed to Strabo as if a new city had suddenly arisen. ${ }^{22}$ Although many standing remains are visible today, the original appearance and arrangement of the villas, imperial palaces, and spa facilities are comparatively ill-understood, for fluctuations in the relative height of land and sea (bradyseism) have substantially altered the coastal topography and render especially difficult the investigation of the lower-lying structures, many of which are now underwater. Nevertheless a vast sector of baths, imposing buildings to enclose the hot springs and sulphurous vapours, grandiose rooms, and extensive loggias and porticoes have all been identified in the multi-level complex terraced into the volcanic slope above the Baian Gulf (plate 1). ${ }^{23}$

One of the most striking buildings is the so-called "Temple of Mercury", a huge rotunda built of tufa and cement with high windows for light and ventilation and a circular skylight at the top of the dome. It closely resembles Hadrian's Pantheon in Rome, though it is only half the size and is thought to have been built over a century earlier. Unlike the Pantheon the "Temple of Mercury" was no temple but a natatorium, where spa visitors could immerse themselves in curative thermal waters. The surroundings were sumptuous: the healing waters entered the building through a nymphaeum; statues adorned wall niches; and the walls were lined with panels of coloured marble.

Adjacent to the "Temple of Mercury" are two further bathing complexes. The so-called Terme di Sosandra is arranged on three terraces bounded by grand staircases and comprises a residential quarter, an exedra-and-nymphaeum with a round pool in an orchestra, and a vast rectangular open-air swimming pool, 34.8 by 28.6 metres. Nearby are the "Baths of Venus", whose most striking unit, the "Temple of Venus", is another huge, internally circular, domed structure. Built on two levels with a bathing pool occupying the entire lower storey, it recalls the singular rotunda at the Pergamene sanctuary of the healing god Asklepios, which also appears to have been used for medicinal bathing or some other form of hydrotherapy. ${ }^{24}$

The grandiose scale and imposing architecture of Baiae, which above all highlight the Roman penchant for terraced buildings enjoying sea vistas, are illuminated, albeit schematically, by engraved scenes on a series of glass bottles (figure 2). These bulbous

${ }^{21}$ Strabo, Geography, V, iv, 7 (C 246).

22 Ibid. J. H. D'Arms, Romans on the Bay of Naples, Cambridge, Mass., Harvard University Press, 1970, esp. $119 \mathrm{ff}$.

23 A. Maiuri, I Campi Flegrei, Rome, Istituto Poligrafico dello Stato, 1963, pp. 72-86. Idem, 'Il restauro di una sala termale a Baia', Boll. d'Arte, 1930-31, 2(10): 241-55. A. de Franciscis, 'Underwater discoveries around the Bay of Naples', Archaeol., 1967, pp. 212-14. H. Comfort, 'Baiae', in R. Stillwell (ed.), The Princeton encyclopaedia of classical sites, Princeton University Press, 1976, pp. 137-8. M. Borriello and A. D'Ambrosio, Baiae-Misenum, Forma Italiae, Regio I, vol. 14, Florence, 1979, esp. pp. 59-73.

24 C. A. Behr, Aelius Aristides, Amsterdam, Hakkert, 1968, pp. 27-8. O. Ziegenaus, Altertümer von Pergamon XI, 3: Das Asklepieion, Teil 3, Berlin, W. de Gruyter, 1981, pp. 76-100 ('Der unterer Rundbau'), although this interpretation is not universally accepted. 


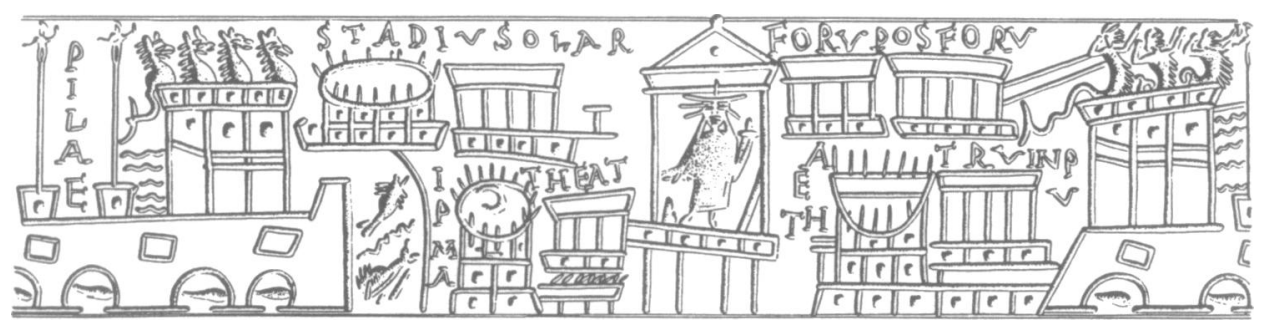

Figure 2. The highlights of Roman Puteoli are depicted in this engraved scene on a bulbous glass bottle from North Africa. Part of the inscription refers to a sun terrace (solar [ium]), while a statue of the rayed sun-god Sol stands in a temple portico. (Drawing P. Compton).

flasks, probably made locally in the third to fourth centuries AD for sale as souvenirs, may well have been used by visitors wishing to drink the spa water. The engraved scenes, which can fairly be described as idealized "snapshots", show the most famous sights and amenities of Baiae and neighbouring Puteoli-a profusion of prestige buildings and structures, in tiers or terraces, including theatres, amphitheatres, temples, baths and sun terraces, as well as the renowned oyster beds of the Lucrine Lake. ${ }^{25}$ The cult statue shown in the open portico of the temple on four of these flasks is a male deity holding a torch and wearing a radiate crown representing the sun's rays. This must be Apollo or the sun-god Sol, both most appropriate in a region dedicated to the enjoyment of sun and healing volcanic waters. ${ }^{26}$

Baiae was a fully-developed resort, patronized by the very wealthy, who demanded luxury and amusement in addition to spa therapy. Elsewhere spas were often rather more modestly appointed. ${ }^{27}$ They were still considered to be important amenities, however, and mineral and thermal spring sites were systematically developed as the Romans encountered them in newly-conquered lands. Few provinces lacked a major spa and in some areas they were particularly numerous, as in the provinces of Germany and Gaul, where water deities had a special significance in Celtic religion. The majority already had resident native deities or spirits, and many were directly associated with healing cults, for the phenomenon of hot or healing waters emerging from the depths of the earth must always have inspired a sense of wonder at the awesome powers of the gods. When a new shrine was to be set up Vitruvius specified the selection of "the most healthy sites with suitable springs... especially for Aesculapius and Salus; and generally for those gods by whose medical power sick persons are manifestly healed." 28

Under Roman rule a native deity, whether of purely local or of wider significance, was usually conflated with a Graeco-Roman divine counterpart chosen for the broad similarity of its powers and spheres of influence. The Gallic and Germanic healing deities were frequently identified with Apollo the Healer, as at the shrines of Essarois,

\footnotetext{
${ }^{25}$ K. S. Painter, 'Roman flasks with scenes of Baiae and Puteoli', J. Glass Stud., 1975, 17: 54-67.

${ }^{26}$ Compare the more explicit connection of Sol with the hot healing waters of Bath: B. Cunliffe and P. Davenport, The temple of Sulis Minerva at Bath, vol. 1, The site, Oxford University Committee for Archacology Monograph 7, 1985, pp. 57-8, fig. 35, pp. 115-16, 120, 183.

${ }^{27}$ See Pliny the Younger, Letters, VIII, 8, for an atmospheric description of a small shrine at an Italian spring site.

${ }^{28}$ Vitruvius, De Arch., I, ii, 7.
} 


\section{Ralph Jackson}

near Dijon, and Hochscheid, near Bernkastel. At Aachen, Apollo joined the native deity Grannus to preside over an important group of thermal springs. ${ }^{29}$ There, as at many other spas, a military presence was the key to development. In the decades around the turn of the first century $A D$, detachments from Legion VI and Legion XXX, which were stationed at Neuss and Xanten on the lower Rhine frontier, constructed two bathing complexes above the hot sulphur springs, the so-called Büchelthermae and the Münsterthermae. These combined the normal suites of rooms of graded temperature and humidity, common to most Roman thermae, with large swimming pools and immersion baths, which were fed by the healing "springs of Grannus". Two Romano-Celtic temples lay in a sanctuary at the heart of the spa, underlining the importance accorded to divine influence.

A votive altar found in one of the suburbs of Aachen and dated to the early second century AD shows what may have been the cult image of Apollo-Grannus (plate 2). ${ }^{30}$ The enthroned god holds a lyre and plectrum and carries his bow and quiver of arrows over his right shoulder. An inscription records that the altar was dedicated "in fulfilment of a vow" by $L$. Latinius Macer, a native of Verona and senior officer (praefectus castrorum) of the Ninth Legion, who may have been restored to health at the spa. Aachen may also have hosted a more eminent spa visitor, for ApolloGrannus was one of the great healing deities whose sanctuaries were visited by the ailing emperor Caracalla in his "tour of the shrines" in AD 211-17."31

The commitment of considerable military resources to the construction of spa installations was not a case of Roman altruism but one of self-interest. Provision was needed for sick and wounded soldiers to recuperate, and though some would have been granted a period of sick leave at home or in a billet others were sent to coastal resorts or spas. ${ }^{32}$ Spas also served as rest and recreation centres for healthy soldiers, and their presence could help boost the general prosperity of the region. However the attractions of a spa could also bring trouble, as is evident in a petition to the emperor Gordian III in AD 238: the residents of the Thracian village of Scaptopara complained of soldiers and minor officials who frequented the neighbouring health resort and demanded free food and lodging. ${ }^{33}$

Roman military involvement has also been inferred at the Swiss spa of Baden (Aquae Helveticae), which seems to have served the legion at nearby Vindonissa. Despite the presence of modern bathing installations above the ancient remains, limited excavations have taken place. In 1967 they revealed part of a baths complex

29 J. J. Hatt, 'Apollon guérisseur en Gaule ... . ', in Pelletier (ed.), op. cit., note 4 above. W. Dehn, 'Ein Quellheiligtum des Apollo und der Sirona bei Hochscheid, Kr. Bernkastel', Germania, 1941, $25: 104-11$. H. Cüppers, Aquae Granni: Beiträge zur Archäologie von Aachen, 1982. L. Hugot, 'Die römischen Büchelthermen in Aachen', Bonner Jb., 1963, 163: 188-97.

${ }^{30}$ H. Nesselhauf and H. v. Petrikovits, 'Ein Weihaltar ... aus Aachen-Burtscheid', ibid., 1967, 167 : 268-79.

${ }^{31}$ Dio Cassius, Hist., LXXVIII, 15, 3-7. H. Engelmann et al., Die Inschriften von Ephesos, Vienna, Osterreichische Akademie der Wissenschaft/Rheinisch-Westfälische Akademie der Wissenschaften, III, (1980), no. 802.

32 Note, for example, the many military inscriptions and tombstones at Bath: $R I B 139,143-4,146-7,152$, 156-60. R. W. Davies, 'The Roman military medical service', Saalburg Jb., 1970, 27: 84-104. esp. p. 100.

${ }^{33}$ CIL III, 12336. M. Rostovtzev, The social and economic history of the Roman empire, 2nd ed., Oxford, Clarendon Press, 1957, pp. 478-9. 


\section{Waters and spas in the classical world}

cut into the gravel slope from which the hot springs emerge. ${ }^{34}$ The structures include a series of basins and pools supplied with running hot water from the springs by a system of stone channels and conduits. One of the pools was provided with stepped sides permitting perhaps as many as 100 bathers to sit immersed in the $45^{\circ} \mathrm{C}$ water. The same arrangement existed at the Black Forest spa of Badenweiler, where the ground plan of the baths is more completely known. ${ }^{35}$ The god of the Baden spring appears to have been Mercury, the subject of bronze and stone statues and dedicatee of several votive offerings. ${ }^{36}$

Another building at Baden, excavated in the 1890s, was found to contain a considerable number of "medical" instruments, and its walls incorporated stamped legionary tiles. In consequence it was identified as a military hospital or clinic, a use which, though unproven, accords well enough with the recorded ground plan. ${ }^{37}$ Most of the instruments are undiagnostic and could equally well have been used in toiletry. However, amongst them was part of a bronze male catheter, the second Roman example known from Baden, and a singularly appropriate medical instrument to have been found at a spa: urinary complaints must have been commonly treated and relieved by spa therapy, then as now. The catheters also serve as a reminder that spas attracted physicians as well as patients, just as physicians were drawn to the crowds of potential customers at town baths. ${ }^{38}$

One of the principal Romal spas of the western empire was at Bath (Aquae Sulis), where archaeologists have gradually, painstakingly, and spectacularly revealed the remains and reconstructed the appearance of the temple and bathing complex. ${ }^{39}$ The hot springs, which were the reason for the establishment of the town, were the focus of the occupied area. Their presiding deity was Sulis-Minerva, a conflation of the little-known Celtic deity Sul or Sulis, and the Roman goddess of learning and crafts, Minerva, who also had a healing aspect as Minerva Medica. An early discovery at Bath was the fine gilt-bronze head of Minerva from a life-size statue, perhaps the cult image itself. Equally striking is the temple pediment sculpture which includes two thoroughly classical winged victories flanking a central "Gorgon's head", a classical motif, but here carved in uncompromisingly Celtic style.

This blending of two very different iconographic traditions aptly mirrored the twinning of Minerva and Sulis. Furthermore, the Gorgon sculpture possesses

\footnotetext{
${ }^{34}$ H. R. Wiedemer, 'Die Entdeckung der römischen Heilthermen von Baden-Aquae Helveticae 1967', Jber. Ges. pro Vindonissa, 1967, pp. 83-93.

${ }^{35}$ H. Mylius, Die römischen Heilthermen von Badenweiler, Römisch-germanische Forschungen 12, Berlin, 1936.

${ }^{36}$ Wiedemer, op. cit., note 34 above, pp. 91-2. M. Hartmann, 'Neue Grabungen in Baden-Aquae Helveticae 1973', Jber. Ges. pro Vindonissa, 1973, pp. 45-51, fig. 5.

37 J. Heierli, Anz. schweiz. Altertumskunde, 1895, 28: 434 f., 458 f. F. Staehelin, Die Schweiz in römischer Zeit, 3rd ed., Basle, 1948, p. 487. C. Unz, 'Römische Militärfunde aus Baden-Aquae Helveticae', Jber. Ges. pro Vindonissa, 1971, pp. 41-58, esp. pp. 41-5 and fig. 1.

38 J. S. Milne, Surgical instruments in Greek and Roman times, Oxford, Clarendon Press, 1907, pp. 144-5. Künzl, op. cit., note 6 above, pp. 491-509. B. Cunliffe, Roman Bath discovered, London, Routledge \& Kegan Paul, 1984, p. 190.

${ }^{39}$ Idem, Roman Bath, Society of Antiquaries Research Report 24, Oxford, 1969. Idem, 'The excavation of the Roman spring at Bath 1979', Antiq. J., 1980, 60: 187-206. Idem, op. cit., note 38 above. Cunliffe and Davenport, op. cit., note 26 above.
} 


\section{Ralph Jackson}

characteristics reminiscent of both sun and water deities and it was probably designed as an intentional expression of the combined power of both gods, together regarded as the creators of hot springs. ${ }^{40}$ Another low-relief sculpture group, from the pediment above the monumental doorway which linked the temple precinct to the sacred spring, is more explicit. It shows the rayed head of the sun-god Sol in a roundel held aloft by two water nymphs astride a rock from which the spring waters gush. ${ }^{41}$

The King's Bath spring, the most prolific of the three hot springs which surface in Bath, delivers a constant flow of about a quarter of a million gallons of water a day at a temperature of $46.5^{\circ} \mathrm{C}$. The water contains some thirty minerals, including calcium, magnesium, potassium, iron, lead, and strontium. It tastes of sulphur and bismuth, is slightly radioactive, and is still valued for treating rheumatic patients. With consummate skill, Roman engineers enclosed the spring-head in a reservoir, drained the surrounding area, and constructed a temple precinct and monumental range of baths around the spring. This massive and carefully integrated complex of classical buildings, constructed within a few decades of the Roman conquest of Britain, must have been an awesome sight to native Briton and Roman alike.

The spring itself was incorporated in the south-east corner of the temple precinct where the baths abutted, and it was the unifying link between the two. The baths, which were intended initially to be a curative adjunct to the temple rather than an independent healing facility, were conceived as three separate units. A spacious hall provided access on the west to a suite of artificially heated rooms and on the east to a much larger range comprising a series of indoor swimming pools served by the thermal spring. The hot spring water was channelled first to the Great Bath, a rectangular lead-lined pool, 24.5 by 11.5 metres, which occupied almost the entire central area of a huge and imposing aisled hall (plate 3). The water was a metre and a half deep and access to it was gained by four steep steps continuous along all four sides. As at Baden and Badenweiler, this feature allowed large numbers of people to sit at various levels in the healing waters. Niches in the aisle walls probably held statues, and at least one fountain was contrived. An outfall pipe on the east side of the Great Bath conveyed the water to a much smaller rectangular pool which in turn fed into a third and slightly smaller pool. The overall result was a range of thermal pools of graded size, grandeur, and water temperature.

Like the temple precinct, the baths complex underwent elaboration and change during some four centuries of use: an additional suite of thermae was added at the east end, perhaps to simplify the provision of separate bathing facilities for both sexes, or to segregate the sick from the healthy; the western suite of baths was modified to include sauna-type facilities-a cold plunge, and a laconicum which provided intense dry heat; $;^{42}$ and curative immersion was extended by the provision of small sunken baths with an underwater stone bench on which patients sat up to their neck in cold water.

\footnotetext{
${ }^{40}$ I. A. Richmond and J. M. C. Toynbee, 'The temple of Sulis-Minerva at Bath', J. Roman Stud., 1955, 45: 97-105. Cunliffe and Davenport, op. cit., note 26 above, pp. 114-16.

41 Ibid., pp. 119-20.

42 Celsus recommended the laconicum for the inducement of "dry sweating" to disperse harmful humours, treat "diseases of sinews", and to clear excess humour (water under the skin) in dropsy patients (De Med., II, 17, 1; III, 20).
} 
Although we lack any contemporary account of the functioning of the Roman spa at Bath, we may assume that the bathers there sought cures for a wide range of diseases and symptoms. As in more recent times, many must have found relief from gout, rheumatism, and arthritis (plate 4). Galen recommended spa therapy particularly for diseases of the joints and urinary tract, while Celsus believed swimming in medicinal springs helped in the treatment of various kinds of paralysis. Augustus' method of "taking the waters" was described by Suetonius. ${ }^{43}$ "When however he had to use hot salt water and sulphur baths for rheumatism, he contented himself with sitting on a wooden bath-seat ... and plunging his hands and feet in the water one after the other." Those less mobile than Augustus might require special arrangements, as is clear from a passage in Soranus stipulating the form of treatment for patients with paralysis of the legs: ${ }^{44}$ "Have the patient use mineral waters, especially warm springs . . . and prescribe swimming in the sea or in these springs. At first an inflated bladder should be attached to the paralysed parts to reduce the effort required in swimming. Also direct a stream of water . . . upon the paralysed parts, for the strong impact of the water is very effective in altering the condition of the body."

The steaming spring at Bath must always have been a dominant feature of the temple-baths complex. By the later second century AD it was enclosed in a huge vaulted chamber and embellished by the addition of several statues supported at water level on pedestals erected within the reservoir. Though access was by then restricted, devotees and grateful suppliants had originally been able to approach the spring from the temple or the baths to contemplate the holy waters and throw in their votive offerings. These were normally of a comparatively modest nature, mostly coins of low denomination. ${ }^{45}$ If, as seems probable, many of these gifts were offered up in gratitude for cures bestowed by Sulis-Minerva, we can only guess at what the afflictions were, for it was evidently not customary to dedicate anatomical ex-votos at Aquae Sulis. There are only two possible examples, a fragmentary bronze breast, and an amulet of breasts carved in elephant ivory.

Over twenty vessels of silver, pewter, and bronze were found within or immediately outside the spring reservoir. Of the eleven found in the portion of the deposits excavated in 1979-80, eight are examples of a distinctive Roman deep-bowled pan with flat handle sometimes, misleadingly, described as a patera. ${ }^{46} \mathrm{Six}$ of these bear scratched or punched inscriptions dedicating them "to the goddess Sulis" or "to the goddess Sulis Minerva". This type of pan was commonly employed in religious ceremonies and rituals, as in the pouring of libations and serving of wine, but the Bath vessels may have been used more specifically as dipping pans for serving draughts of spring water to the spa patients. All eight pans came from the scree of material beneath the central arched opening on the south side of the spring. In other words they were dropped into the spring not from the temple side, access to which by the

${ }^{43}$ Celsus, De Med., III, 27; IV, 12, 7. Suetonius, Lives, Augustus, lxxxii, 2.

44 Caelius Aurelianus, On chronic diseases, 2, 44-8 (transl. I. E. Drabkin, Bull. Hist. Med., 1951, 25: 511).

${ }^{45}$ B. Cunliffe (ed.), The temple of Sulis Minerva at Bath, vol. 2, The finds from the sacred spring, Oxford University Committee for Archaeology Monograph 16, 1988.

${ }^{46}$ On the identification of patera, see W. Hilgers, Lateinische Gefässnamen, Düsseldorf, RheinlandVerlag, 1969, pp. 71-2. 


\section{Ralph Jackson}

third century appears to have been restricted to the priests, but from the baths side which, though cut off from the baths around AD 200, became the sole approach to the waters for patients and suppliants. Deep-bowled pans found at other spas and healing temples include four from Baden, two of which were dedicated to Mercury by $T$. Cammianius Bacchus "gladly and willingly in fulfilment of a vow", perhaps after a successful spa treatment; and one from Augst inscribed with a dedication to the Gallic healing pair Apollo and Sirona. ${ }^{47}$

Spa water was sometimes consumed in legendary quantities, on the assumption that if a little did you good a lot must do you a lot of good. Pliny the Elder castigated not just those who bathed overlong in hot sulphur springs, but also those who through ignorance or bravado drank excessive quantities of medicinal waters: ${ }^{48}$ "Those make a like mistake who boast of the great quantity they can drink. I have seen some already swollen with drinking to such an extent that their rings were covered by skin, since they could not void the vast amount of water they had swallowed."

A broken silver and gilt pan handle, from a hoard of silver buried at Capheaton, Northumberland sometime in the third century, bears a very apposite scene: Minerva presiding over a sacred spring (plate 5). ${ }^{49}$ The goddess stands commandingly with her foot on an upturned vessel from which water gushes, a symbol of her power over the healing waters. The spring runs between a classical temple and a small structure, probably a fountain house, from which a figure appears to be taking a draught of water. It is very tempting to regard this scene in a similar light to those on the Baiae/Puteoli glass flasks, in this case as a stylised representation of not simply $a$ healing spring of Minerva, but of the healing spring of Sulis-Minerva at Bath. Certainly Aquae Sulis was an important and famous Roman spa, and just as Pliny the Younger sent his wife to the Campanian resorts for her health ${ }^{50}$ so we may imagine a similar custom in Britain, with wealthy families taking full advantage of the health-giving waters and resplendent surroundings of Aquae Sulis.

The drinking of spa water is illustrated on another silver vessel, a bowl from Otañes, near Castro Urdiales in northern Spain (plate 6). ${ }^{51}$ The scene, on the inside of the bowl, is encircled by an inlaid gilt inscription, SALUS UMERITANA. Salus, whom the Romans equated with Hygieia, the Greek goddess of health, was clearly the presiding deity of the hitherto unknown medicinal spring of Umeri, which was probably located in the Pyrenees. The scene is divided into a series of vignettes to provide the fullest picture of the spa in operation. At the top Salus is shown reclining, with her left arm symbolically controlling the flow of spring water from an urn. The water runs into a tank or reservoir from which a figure, perhaps a temple servant, scoops water and pours it into a large churn-like jar. Nearby, a native traveller or shepherd places offerings on an altar, and an elderly man, dressed in a toga, sits in a wicker chair attended by a young servant who has brought him a cup of spring water. Another

\footnotetext{
${ }^{47}$ Baden: Wiedemer, op. cit., note 34 above, pp. 91-2. Augst: Staehelin, op. cit., note 37 above, p. 541.

48 Nat. Hist., XXXI, xxxii. See also Nat. Hist., XXIX, v, 10.

${ }^{49}$ H. B. Walters, Catalogue of the silver plate ... in the British Museum, London, 1921, pp. 50-1, fig. 52.

${ }^{50}$ Letters, VI, 4.

51 CIL, II, 2917. Rostovtzev, op. cit., note 33 above, pl. XXXV, 2.
} 


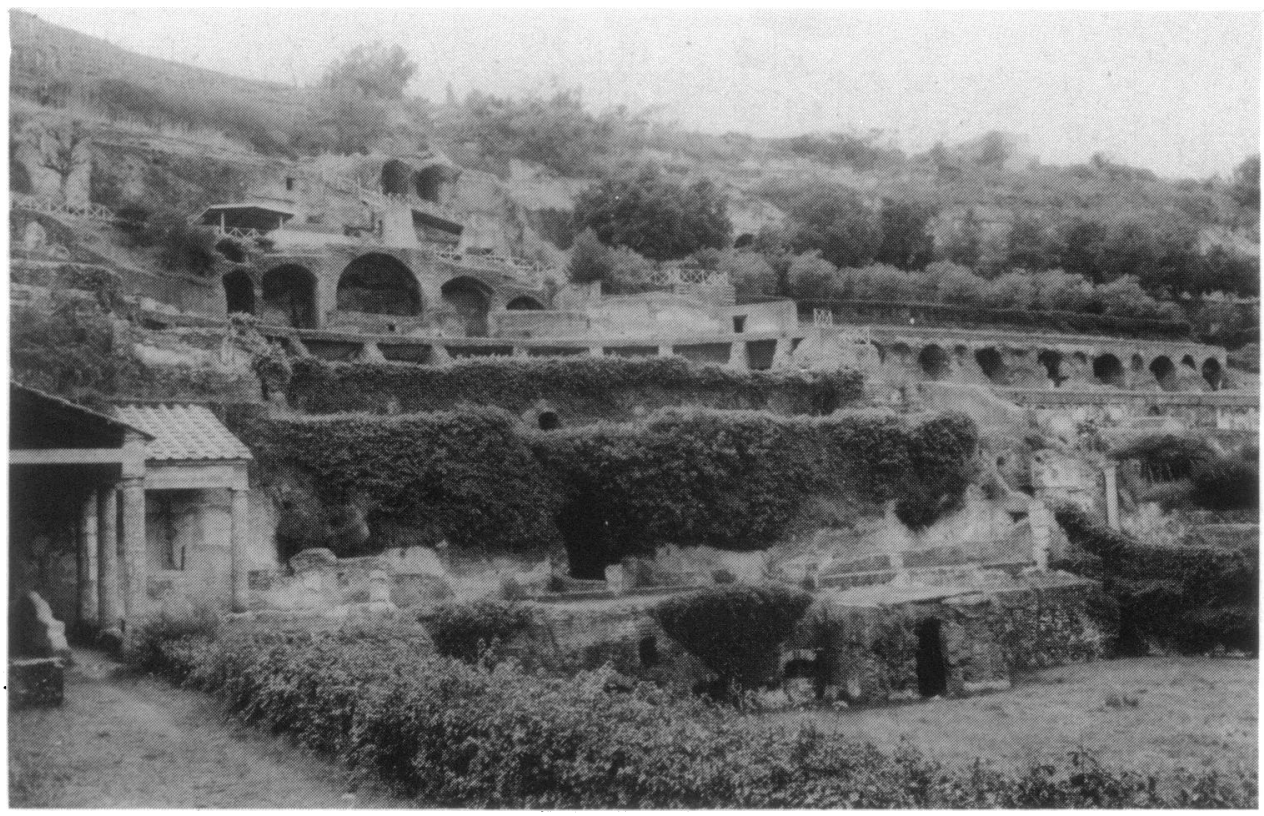

Plate 1. Baiae, the baths of Sosandra, terraced into the side of an extinct volcanic crater. 


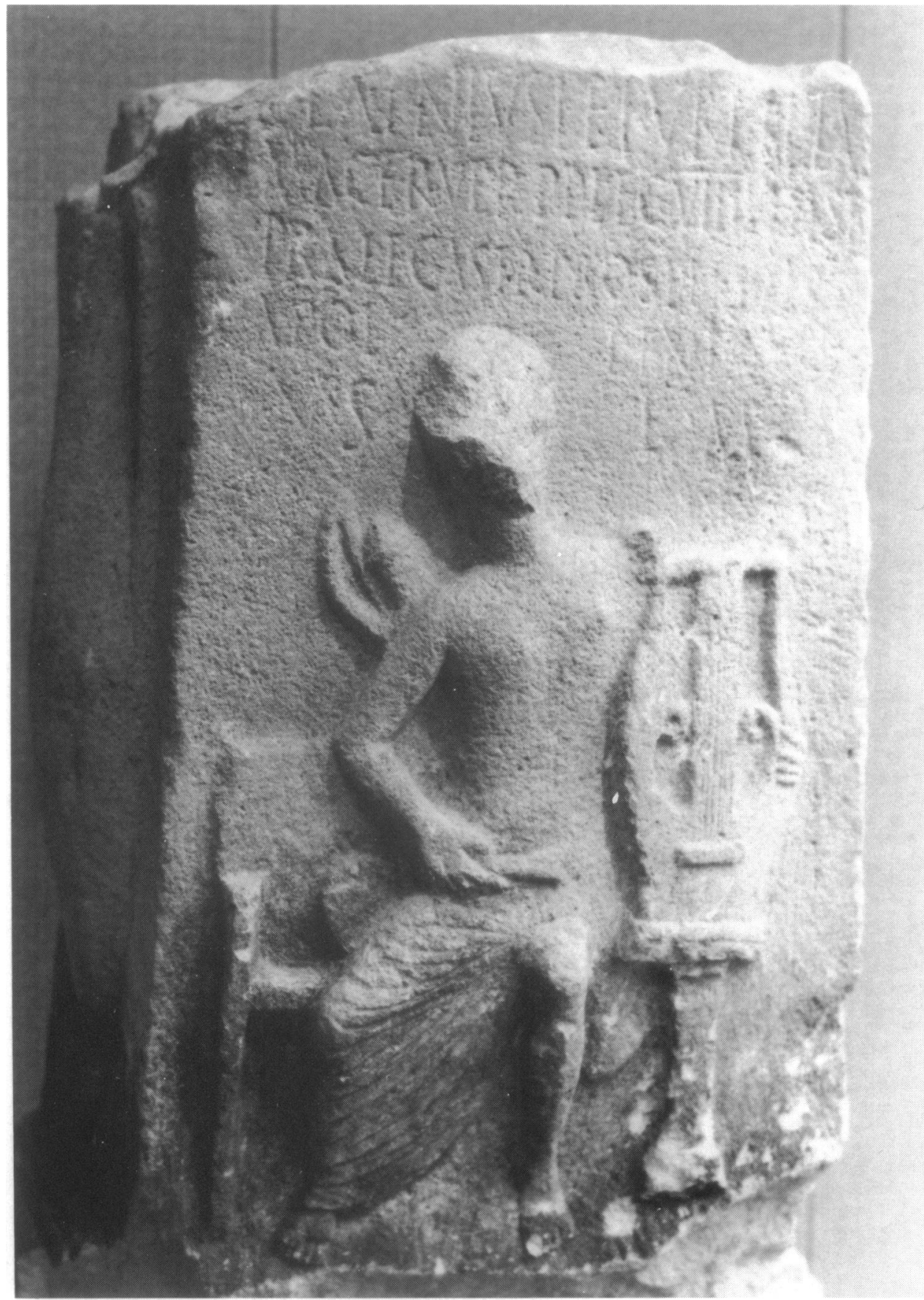

Plate 2. Votive altar from Aachen-Burtscheid showing Apollo (perhaps a depiction of the cult image of Apollo-Grannus) with characteristic attributes. The upper part of the inscription is missing. (Bonn, Rheinisches Landesmuseum. Photo, author). 


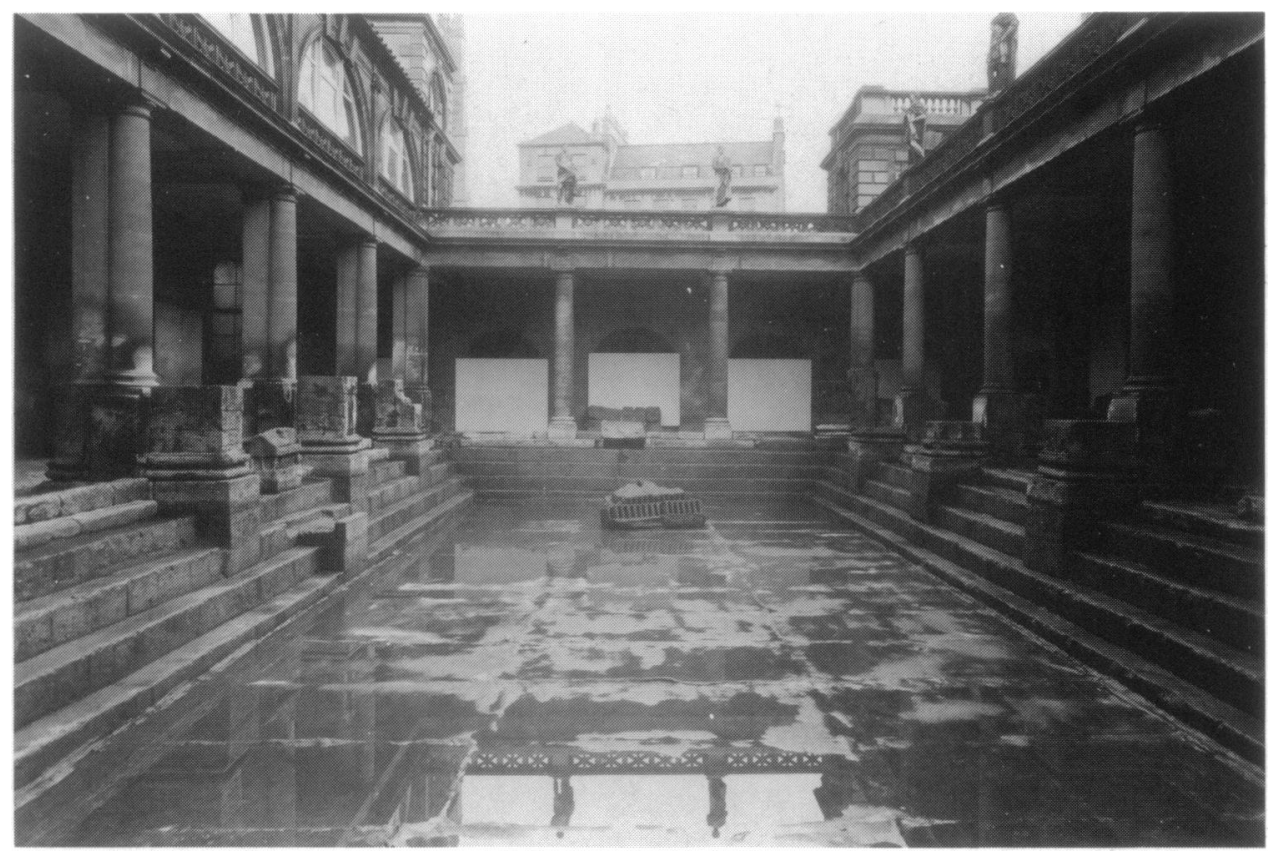

Plate 3. The Great Bath at Bath. In the Roman period the bath was enclosed, and the bases of the piers that supported the massive roof are visible beneath and beside the modern columns. Temporary drainage of the pool reveals its lead-lined floor and stepped seating around the sides. (Photo, Bath Archaeological Trust).

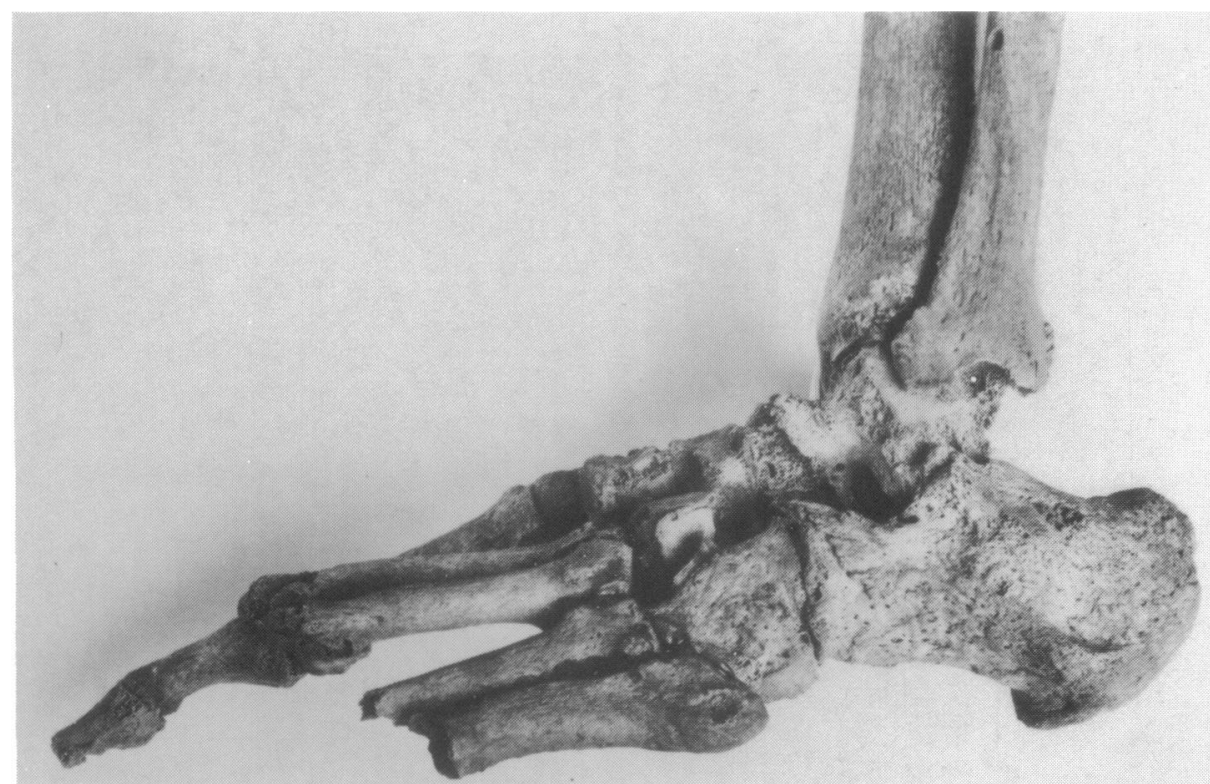

Plate 4. Gout has been diagnosed in this and two other skeletons from a late Roman cemetery at Cirencester. Relief could have been found in the hot springs of Sulis Minerva at nearby Bath. Right foot of Inh. 42. Bath Gate cemetery. (Photo, Dr Calvin Wells, and the Calvin Wells Laboratory for Burial Archaeology, School of Archaeological Sciences, University of Bradford). 


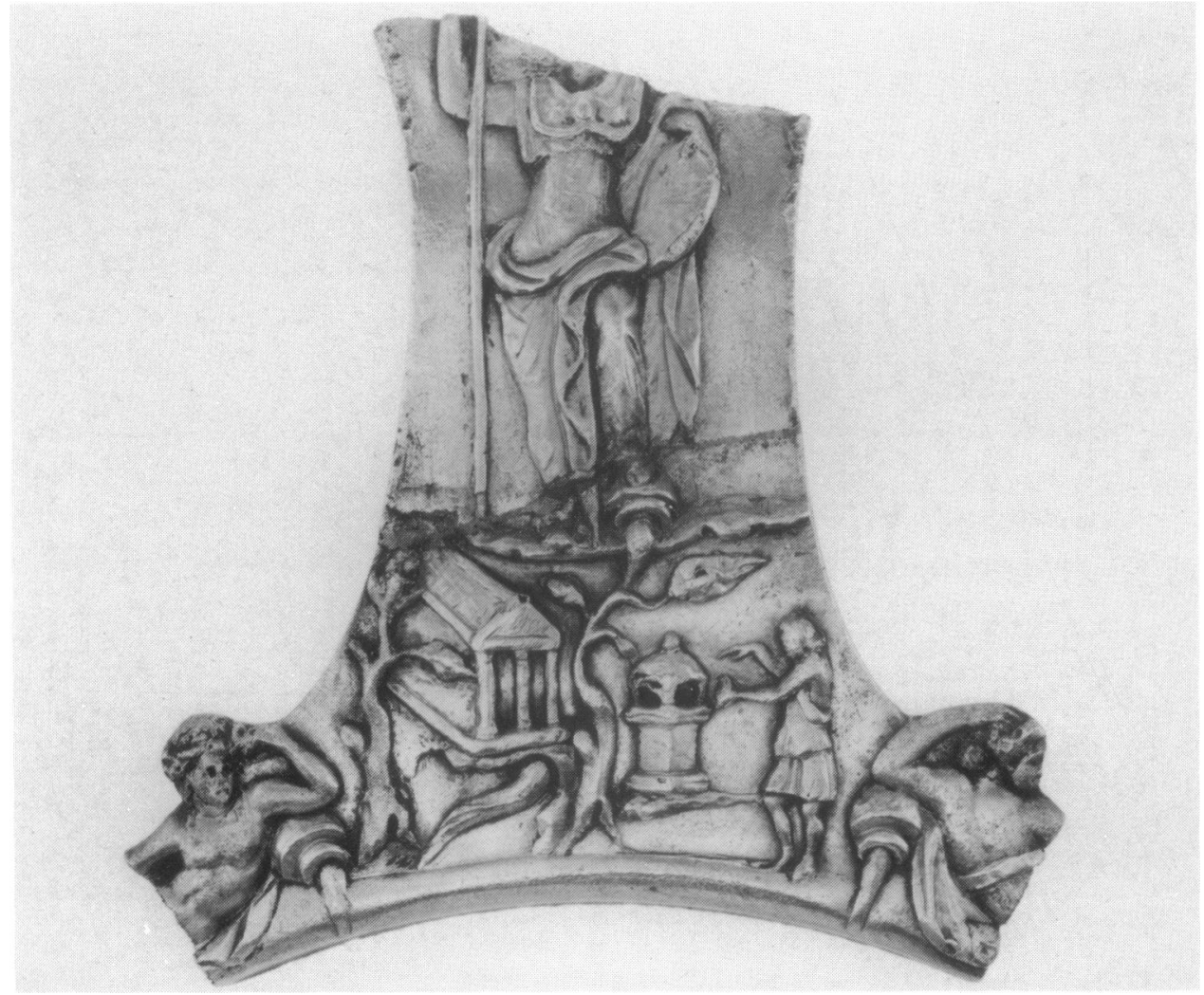

Plate 5. Silver and gilt pan handle showing Minerva presiding over a sacred spring. Width $8.5 \mathrm{~cm}$. Capheaton Hoard, Northumberland. (The Trustees of the British Museum).

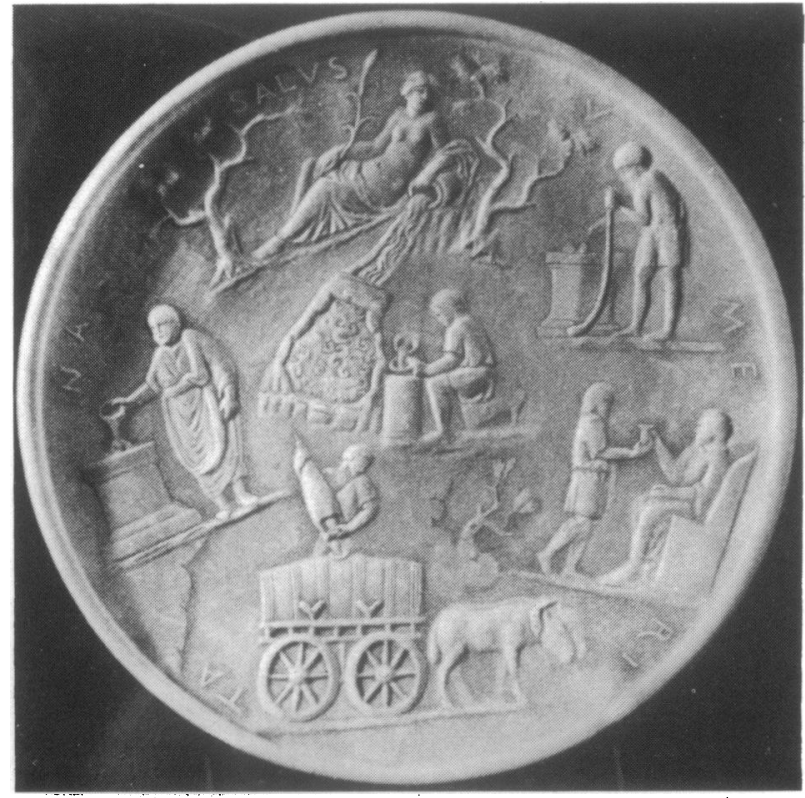

Plate 6. Silver and gilt bowl ornamented in low relief with scenes of the Spanish spa of Salus Umeritana. Dia. $21.1 \mathrm{~cm}$. From Otañes, Castro Urdiales, N. Spain. (Photo of plaster cast, Museo de Reproducciones Artisticas, Madrid). 


\section{Waters and spas in the classical world}

elderly toga-clad man, probably the same one, is shown sacrificing at an altar, presumably in thanks for a cure. Finally, a pair of mules waits patiently while a huge barrel on their cart is filled with spa water by another young figure, again perhaps a temple servant, carrying an amphora. The spa of Salus Umeritana was evidently sufficiently celebrated for the waters to be "bottled" and transported to those who were unable to make a visit. It may even have been one of the Pyrenean spas visited by Augustus. As in more recent times, royal patronage was immensely influential in shaping public attitudes and fashions, and the visits and interest of emperors such as Augustus and Caracalla must have brought prosperity not only to individual healing sanctuaries and curative springs but also to spas in general.

In summary, water was frequently, widely, and enduringly used in classical medicine. There was a keen appreciation of the specific and general properties of different types of water, and that from mineral and thermal springs was particularly valued. The principal spas attracted very large numbers of visitors, among whom the wealthiest made generous benefactions which sometimes brought an architectural splendour equal to that of the prestige buildings of major towns. In such surroundings the healing springs were employed in many different ways. The waters (sometimes the spring muds, too ${ }^{52}$ were applied locally to afflicted parts of the body; swimming and static immersion were common treatments, above all for rheumatic and urinary diseases; draughts were freely administered for a host of internal ailments; and last, but not least, the waters were treated as a source of enjoyment and delectation. The regimens and general ambience of some of these spas cannot have been so very different to those of the watering places of nineteenth-century Europe.

52 Pliny, Nat. Hist., XXXI, xxxii. 